Abstracta Iranica

Revue bibliographique pour le domaine irano-aryen

Volume 37-38-39 | 2018

Comptes rendus des publications de 2014-2016

\title{
Peter Stein. « Ein aramäischer Kudurru aus Taymā'? »
}

\section{Astrid Nunn}

\section{(2) OpenEdition \\ 1 Journals}

\section{Édition électronique}

URL : http://journals.openedition.org/abstractairanica/42621

DOI : 10.4000/abstractairanica.42621

ISBN : 1961-960X

ISSN : 1961-960X

Éditeur :

CNRS (UMR 7528 Mondes iraniens et indiens), Éditions de l'IFRI

Référence électronique

Astrid Nunn, «Peter Stein. «Ein aramäischer Kudurru aus Taymā' ? » », Abstracta Iranica [En ligne],

Volume 37-38-39 | 2018, document 25, mis en ligne le 10 mars 2018, consulté le 28 septembre 2020. URL : http://journals.openedition.org/abstractairanica/42621; DOI : https://doi.org/10.4000/ abstractairanica. 42621

Ce document a été généré automatiquement le 28 septembre 2020

Tous droits réservés 


\title{
Peter Stein. « Ein aramäischer Kudurru aus Taymā'? ?
}

\author{
Astrid Nunn
}

\section{RÉFÉRENCE}

Peter Stein. «Ein aramäischer Kudurru aus Taymā’' ? ", in M. Krebernik, H. Neumann (éds.), Babylonien und seine Nachbarn in neu- und spätbabylonischer Zeit. Wissenschaftliches Kolloquium aus Anlass des 75. Geburtstags von Joachim Oelsner, Jena, 2. und 3. März 2007, (AOAT 369), 2014, Münster, p. 219-245.

1 Tayma, ville située dans le nord-ouest de l'Arabie Saoudite est surtout connue pour avoir été le refuge de Nabonide. Le thème de l'article est la fameuse stèle, envoyée à Paris en 1880 et depuis mise en relation avec le séjour de Nabonide. Sa face consiste en une inscription araméenne nommant ȘLMŠZB, fils de Petosiris. L'A. propose une nouvelle interprétation de la première ligne et, en conséquence, une nouvelle datation non pas néo-babylonienne mais plutôt achéménide. Le verbe șdqw de la ligne 12 ne signifierait pas "être juste» mais «faire un présent» et changerait ainsi la signification globale de cette stèle. Souvent interprétée comme l'indice de la fondation d'un nouveau culte, elle devient un « kudurru », donc un document juridique fixant la jouissance de terrain pour ȘLMŠZB et sa descendance. 


\section{AUTEURS}

\section{ASTRID NUNN}

Université de Munich 